\title{
POPULATION DYNAMICS OF THE MICROBIOTA IN THE LITTER OF TWO TREE SPECIES OF THE ATLANTIC FOREST
}

Fabiana Baldez ${ }^{1}$, Marcos Gervasio Pereira ${ }^{2}$, Tatiana Saldanha ${ }^{3}$, Wilbert Valkinir Cabreira ${ }^{4}$, Cristiane Figueira da Silva ${ }^{4}$, Marcelo Elias Fraga ${ }^{5}$

1Universidade Federal Rural do Rio de Janeiro, Programa de Pós-Graduação em Fitossanidade e Biotecnologia Aplicada, Seropédica, Rio de Janeiro, Brasil - fbnbaldez@gmail.com

2Universidade Federal Rural do Rio de Janeiro, Departamento de Solos, Seropédica, Rio de Janeiro, Brasil - gervasio@ufrrj.br

${ }^{3}$ Universidade Federal Rural do Rio de Janeiro, Departamento de Tecnologia de Alimentos, Seropédica, Rio de Janeiro, Brasil tatysal@gmail.com

${ }^{4}$ Universidade Federal Rural do Rio de Janeiro, Programa de Pós-Graduação em Ciências Ambientais e Florestais, Seropédica, Rio de Janeiro, Brasil - wilbertvalkinir@gmail.com; cfigueirasilva@yahoo.com.br

${ }^{5}$ Universidade Federal Rural do Rio de Janeiro, Departamento de Microbiologia e Imunologia Veterinária, Seropédica, Rio de Janeiro, Brasil - fraga@ufrrj.br

Received for publication: 30/08/2018 - Accepted for publication: 05/03/2020

\begin{abstract}
Resumo
Dinâmica populacional da microbiota associada à serapilheira de duas espécies arbóreas da Mata Atlântica. Visando entender como se dá a dinâmica populacional da microbiota relacionada com a taxa de liberação de nutrientes durante o processo de decomposição da serapilheira, foi feito o estudo com duas espécies arbóreas nativas da Mata Atlântica, o pau-brasil (Paubrasilia echinata) e o ingá (Inga laurina). Foram realizadas seis coletas ao decorrer de 365 dias, para a avaliação da taxa de liberação de nitrogênio $(\mathrm{N})$, fósforo $(\mathrm{P})$ e potássio (K) da serapilheira, a qual acondicionou-se folhas secas, provenientes das espécies escolhidas, em sacos de polivinil, denominados litter bags que foram colocados abaixo de suas respectivas copas de árvores. A fim de identificar os grupos de micro-organismos da serapilheira (fungos, bactérias e actinomicetos), utilizou-se o método de cultivo em placa, através da contagem de Unidades Formadoras de Colônia (UFC), e o método por perfil de ácidos graxos, através de biomarcadores, associando-a a taxa de liberação dos nutrientes e aos fatores abióticos (temperatura e precipitação). Foi observado correlação da taxa de liberação dos nutrientes com os 140 dias de decomposição e correlação entre a maioria dos micro-organismos com 30 dias de decomposição. A taxa de liberação do nitrogênio e do fósforo estavam associadas à precipitação. Houve correlação entre fungos e a taxa de liberação do P na decomposição da serapilheira do ingá. O biomarcador de bactérias 17:1 foi o único que teve correlação com a taxa de liberação de $\mathrm{N}$ e P. Concluindo que, há interferência da precipitação na solubilização de nutrientes das espécies estudadas, há diferença na microbiota entre as espécies e, ao se comparar os dois métodos utilizados para a identificação desses micro-organismos, as informações de um método complementa o outro, uma vez que ambos fornecem dados diferentes, porém, interdependentes.

Palavras-chave: Paubrasilia echinata, Inga laurina, ciclagem de nutrientes.
\end{abstract}

Abstract

This study analyzes microbiota population dynamics as a function of nutrient release rate during litter decomposition. For that, we observed two tree species native to the Atlantic Forest: brazilwood (Paubrasilia echinata) and inga (Inga laurina). To assess nitrogen $(\mathrm{N})$, phosphorus $(\mathrm{P})$, and potassium $(\mathrm{K})$ release rates from the litter, we performed six collections over 365 days. In these collections, we placed polyvinyl bags called 'litter bags' below the treetops of the chosen species to collect dry leaves. To identify the groups of litter microorganisms (fungi, bacteria, and actinomycetes), we used the plate culture method to count the number of colony-forming units (CFU), and the fatty acid profile method, through biomarkers, associating nutrient release rate and abiotic factors (temperature and precipitation). Nutrient release rate correlates with litter decomposition at 140 days, and most microorganisms correlate with litter decomposition at 30 days. Nitrogen and phosphorus release rates correlate with precipitation. Fungi correlate with $\mathrm{P}$ release rate in inga litter decomposition. The bacteria biomarker 17:1 was the only one that correlated with $\mathrm{N}$ and $\mathrm{P}$ release rates. In conclusion, precipitation affects nutrient solubilization in the studied species, and microbiota differs between the species. When comparing the two methods to identify these microorganisms, information from one method complements information from the other, since both provide different but interdependent data.

Keywords: Paubrasilia echinata, Inga laurina, nutrient cycling.

\section{INTRODUCTION}

The Atlantic Forest has a high diversity of species, which directly influences the functioning of this ecosystem. Tropical forests are among the most important carbon stocks in the world (PAN et al., 2011), which makes the knowledge of the interaction between fauna and flora quite relevant for the maintenance and perpetuation of species that live in this habitat. An important factor for the conservation of tree species is nutrient

FLORESTA, Curitiba, PR, v. 50, n. 3, p. 1449 - 1456, jul/set 2020.

Baldez, F. et.al.

ISSN eletrônico 1982-4688

DOI: $10.5380 /$ rf.v50 i3. 61279 
cycling. One way to assess it is by studying litter decomposition as a function of microbiota (URIARTE et al., 2015). Some microorganisms, such as bacteria and fungi, are essential elements for organic matter decomposition and nutrient mineralization (COURTY et al., 2010).

Given the importance of these microorganisms for the perpetuation of tree species, it becomes necessary to conduct in-depth microbiota studies to identify groups of microorganisms. These studies can apply culturedependent methods (isolation in culture medium) or culture-independent methods, using, for example, the $18 \mathrm{~S}$ rDNA library and fatty acid profile analysis. The fatty acid profile is an alternative way to evaluate these decomposer microorganisms, using biomarker fatty acids already used in some microbiota studies to overcome the problem of selectivity in plate culture (MALIK et al., 2016; NARENDRULA-KOTHA and NKONGOLO, 2017).

The nutritional maintenance of little managed or unmanaged forests depends on nutrient cycling through microbial decomposers. In these forest environments, there is a great diversity of microorganisms (YOU et al., 2014), of which mostly remain unstudied. Thus, studying techniques for the identification of microbial communities is essential to extend the knowledge about such microorganisms and their functions in the ecosystem. In this way, the present study evaluates a microbial community acting on litter decomposition. We identified the groups of microorganisms from the fatty acid profile and plate culture, relating microorganisms and the nutrient release rate from decomposing litter of tree species native to the Atlantic Forest.

\section{MATERIALS AND METHODS}

The experimental area was within the Botanical Garden of the Federal Rural University of Rio de Janeiro, on Highway BR-465, Km 7, Seropédica city, Rio de Janeiro State, Brazil (22 $45^{\prime} 54.6^{\prime \prime}$ South latitude and $43^{\circ}$ 41'32 .3" West longitude). We obtained temperature $\left({ }^{\circ} \mathrm{C}\right)$ and precipitation $(\mathrm{mm})$ (Table 1) data from the Agricultural Ecology meteorological station of Seropédica city, Rio de Janeiro State, as provided by the National Meteorological Institute (INMET).

Table 1. Mean temperature $\left({ }^{\circ} \mathrm{C}\right)$ and precipitation $(\mathrm{mm})$ over the 365 days of the experiment, as provided by the Agricultural Ecology meteorological station of Seropédica city.

Tabela 1. Dados temperatura $\left({ }^{\circ} \mathrm{C}\right)$ e precipitação $(\mathrm{mm})$ médias obtidas da estação meteorológica Ecologia Agrícola no Município de Seropédica ao decorrer se 365 dias do experimento.

\begin{tabular}{ccccccc}
\hline Day & $\mathbf{0}$ & $\mathbf{1 0}$ & $\mathbf{3 0}$ & $\mathbf{1 4 0}$ & $\mathbf{2 4 0}$ & $\mathbf{3 6 5}$ \\
\hline Temperature & 22.8 & 23.4 & 23.4 & 28.8 & 24.45 & 21.2 \\
\hline Precipitation & 31.4 & 50.4 & 50.4 & 159.6 & 70.4 & 53.6 \\
\hline
\end{tabular}

For the experiment, we selected the species Paubrasilia echinata (PB) and Inga laurina (I), analyzing three trees for each species. These trees were randomly arranged in the Botanical Garden area, and were approximately 30 years old, with some characteristics as reported in Table 2.

Table 2. Canopy area (AC), diameter at breast height (DBH), and total height (TH) of brazilwood (Paubrasilia echinata) and inga (Inga laurina); Botanical Garden of UFRRJ.

Tabela 2. Área da copa (AC), diâmetro à altura do peito (DAP) e altura total (HT) dos espécimes de pau-brasil (Paubrasilia echinata) e ingá (Inga laurina) no Jardim Botânico da UFRRJ.

\begin{tabular}{cccc}
\hline Species & CA $\left.\mathbf{( m}^{2}\right)$ & DBH $(\mathbf{c m})$ & TH $(\mathbf{m})$ \\
\hline PB1 & 14.65 & 258 & 9.3 \\
\hline PB2 & 32.07 & 144 & 9.8 \\
\hline PB3 & 17.57 & 173 & 9.4 \\
\hline I1 & 33.18 & 330 & 12.5 \\
\hline I2 & 57.96 & 350 & 14.3 \\
\hline I3 & 38.95 & 310 & 13.8 \\
\hline
\end{tabular}

To study litter decomposition, we adapted the technique used by Bocock and Gilbert (1957), collecting green leaves directly from the canopy with a pruner. We dried the leaves in an oven at $65^{\circ} \mathrm{C}$ until constant weight, and packed $10 \mathrm{~g}$ portions into polyvinyl bags (litter bags) with a $4 \mathrm{~mm}$ mesh, $25 \mathrm{x} 25 \mathrm{~cm}$ area, and $1.5 \mathrm{~cm}$ height. We placed 15 litter bags under the canopy of each tree of each species at the beginning of August 2016. We collected the material at intervals of $0,10,30,140,240$, and 365 days, using three litter bags per collection, totaling three replicates per area.

For nutritional analysis, in each collection, we dried the litter bags again in an oven at $65^{\circ} \mathrm{C}$ for $48 \mathrm{~h}$ until constant weight (PINTO et al., 2016). Then, we visually examined the content to remove soil particles, fungi, insects, and other animals, among others. Subsequently, we weighed the material in an analytical balance accurate

FLORESTA, Curitiba, PR, v. 50, n. 3, p. 1449 - 1456, jul/set 2020

Baldez, F. et.al.

ISSN eletrônico 1982-4688

DOI: $10.5380 /$ rf.v50 i3. 61279 
to $0.01 \mathrm{~g}$. For analyzing $\mathrm{N}$ and P levels, we followed the methodology of Tedesco et al. (1995); for $\mathrm{K}^{+}$levels, we followed the method of EMBRAPA (1979).

After obtaining the concentrations, we calculated the nutrient release rate for each collection using the expression below:

$$
\text { Release rate }(\%)=\frac{\text { Concentration of the previos collection }- \text { Concentration of the current collection }}{\text { Concentration of the previos collection }} X 100
$$

To study the microbiota, we removed fresh material from the litter bags in each collection, separating them in defined quantities for plate culture analysis (culture-dependent method) and fatty acid profile analysis (culture-independent method).

For plate culture, we determined the population of each microorganism group by standard counting using the spread plate technique in Martin agar, nutrient agar, casein dextrose starch agar, and methylene blue eosin agar, for identification of fungi, gram-positive bacteria, actinomycetes, and gram-negative bacteria, respectively. We suspended $5 \mathrm{~g}$ aliquots of litter in $45 \mathrm{~mL}$ of $0.85 \% \mathrm{NaCl}$ solution. After strong briskly stirring and decanting, we transferred $0.1 \mathrm{~mL}$ of the suspension to tubes containing $9 \mathrm{~mL}$ of $0.1 \%$ peptone water. We used $10^{-6}$ to $10^{-10}$ dilutions to quantify colony-forming units. Soon afterwards, we removed $0.1 \mathrm{~mL}$ from this solution, followed by drop plating, with 3 replicates for each dilution of microorganisms. We placed Petri dishes in greenhouses at 32 ${ }^{\circ} \mathrm{C}$ for $48 \mathrm{~h}$ for bacteria and actinomycetes, and at $25^{\circ} \mathrm{C}$ for 5 days for fungi, in which readings considered the presence or absence of CFU on each drop.

For the fatty acid profile, we dried the litter in an oven at $35^{\circ} \mathrm{C}$ until constant weight, selecting $2 \mathrm{~g}$ of leaves. Then, we cold-extracted microbial lipids with chloroform using the method of Folch et al. (1957). For esterification, we followed the method of Joseph and Ackman (1992). We quantified fatty acids using a gas chromatograph (Shimadzu, Tokyo, Japan) equipped with a split injector (1:50), a flame ionization detector, and a workstation. Chromatographic separation took place in a gas chromatograph Shimadzu GC-2010 Plus equipped with a CP-SIL 88 fused-silica capillary column (100 $\mathrm{m}$ x $0.25 \mathrm{~mm}$ x $0.20 \mathrm{~mm}$ film thickness). The chromatographic temperature program was: initial temperature of $100{ }^{\circ} \mathrm{C} .5 \mathrm{~min}^{-1}$, followed by $5{ }^{\circ} \mathrm{C} . \mathrm{min}^{-1}$, up to $160{ }^{\circ} \mathrm{C}(0 \mathrm{~min}), 8$ ${ }^{\circ} \mathrm{C} . \mathrm{min}^{-1}$, up to $230{ }^{\circ} \mathrm{C} .12 \mathrm{~min}^{-1}$. Injector and detector temperatures were $250{ }^{\circ} \mathrm{C}$ and $280{ }^{\circ} \mathrm{C}$, respectively. We used hydrogen as a carrier gas, with a flow rate of $30 \mathrm{~mL}$.min. Retention times followed the FAME standards to identify the chromatographic peaks of the samples. We performed quantification by external calibration with a concentration range of 0.3 to $7 \mathrm{mg} . \mathrm{mL}$. We estimated microbial biomass from the total amount of fatty acids (g.100 $\mathrm{g}^{-1}$ of lipid) extracted. Biomarker fatty acids were 14:0, 15:0, 16:0, 17:0, 18:0, 16:1, 17:1 for bacteria, and 18:2 66.9 for fungi (MALIK et al., 2016).

We used the Pearson correlation analysis and principal component analysis to assist in the assessment of the relationship between microorganisms, nutrient release rate, and abiotic factors, enabling the observation of multidimensional data variation in a diagram. With this, we ordered the data on the axes, according to their similarities, around the variables, considering autovector $<0.70$ as a low level for data analysis.

\section{RESULTS}

Sulfuric digestion made it possible to quantify nitrogen, phosphorus, and potassium (Table 3). Comparing the two species studied for their nitrogen, phosphorus, and potassium levels, brazilwood achieved the highest concentrations for all three nutrients, as well as the greatest loss of such nutrients. Nitrogen was the nutrient with the highest concentration in litter, followed by potassium and, lastly, phosphorus, with the least remaining mass.

Table 3. Nitrogen $(\mathrm{N})$, phosphorus $(\mathrm{P})$, and potassium $(\mathrm{K})$ levels in the litter of brazilwood and inga over the 365 days of the experiment.

Tabela 3. Teores de nitrogênio $(\mathrm{N})$, fósforo $(\mathrm{P})$ e potássio $(\mathrm{K})$ extraídos da serapilheira do pau-brasil e do ingá ao decorrer de 365 dias de experimento.

\begin{tabular}{|c|c|c|c|c|c|c|}
\hline \multirow{3}{*}{ Day } & \multicolumn{3}{|c|}{ Brazilwood } & \multicolumn{3}{|c|}{ Inga } \\
\hline & \multicolumn{6}{|c|}{ g.kg-1 } \\
\hline & $\mathbf{N}$ & $\mathbf{P}$ & $\mathbf{K}$ & $\mathbf{N}$ & $\mathbf{P}$ & $\mathbf{K}$ \\
\hline 0 & 39.09 & 3.42 & 6.72 & 34.45 & 2.11 & 4.95 \\
\hline 10 & 37.98 & 2.96 & 4.84 & 33.1 & 2.07 & 3.3 \\
\hline 30 & 37.04 & 2.71 & 4 & 31.8 & 1.98 & 2.52 \\
\hline 140 & 32.5 & 2 & 1.2 & 29.6 & 1.8 & 0.5 \\
\hline 240 & 31.35 & 1.85 & 0.65 & 28.94 & 1.74 & 0.29 \\
\hline 365 & 30.35 & 1.82 & 0.27 & 28.25 & 1.68 & 0.11 \\
\hline $\begin{array}{c}\text { Remaining } \\
\text { Mass }\end{array}$ & 8.74 & 1.6 & 6.45 & 6.20 & 0.43 & 4.84 \\
\hline
\end{tabular}

FLORESTA, Curitiba, PR, v. 50, n. 3, p. 1449 - 1456, jul/set 2020.

Baldez, F. et.al.

ISSN eletrônico 1982-4688

DOI: $10.5380 /$ rf.v50 i3. 61279 
The plate culture method showed correlation of all microorganisms (bacteria, fungi, and actinomycetes) with litter decomposition at 30 days for both species (Figure 1a; Figure 1b), with the exception of fungi in the inga, which correlated with litter decomposition at 240 days (Figure 1b). However, the fatty acid profile showed correlation between bacteria and fungi biomarkers and litter decomposition between 240 and 365 days for brazilwood (Figure 1c). For inga, the biomarkers correlated with litter decomposition at three different periods: 10, 30, and 365 days (Figure 1d). It is noteworthy that, in both tree species, 17:1 (which is one of the biomarkers of bacteria) was the only fatty acid that correlated with litter decomposition at 140 days (Figure 1c; Figure 1d).

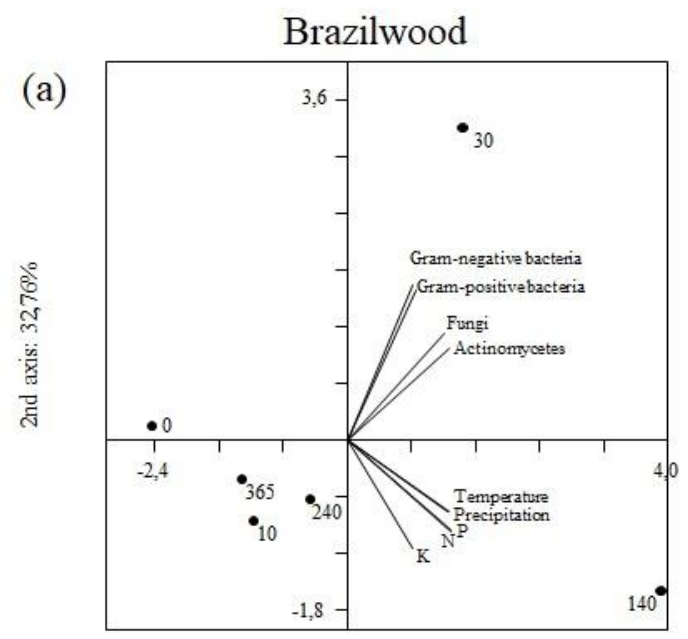

1st axis: $59,12 \%$

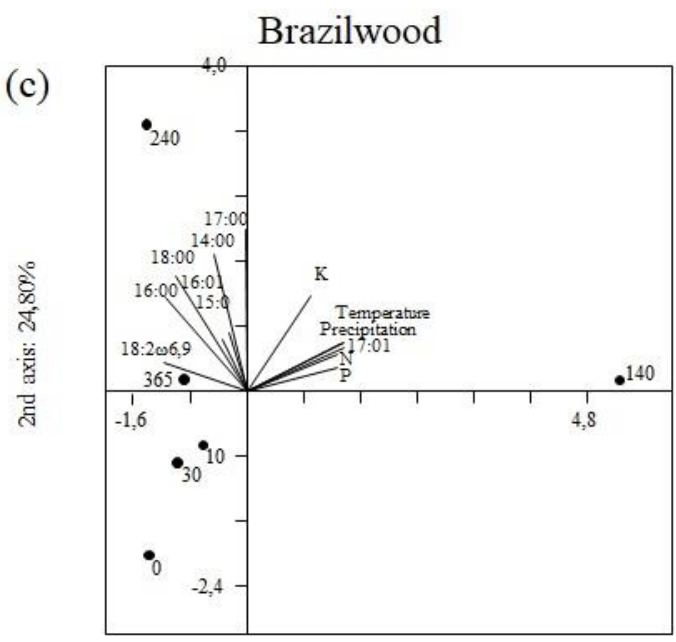

1st axis: $52,0 \%$

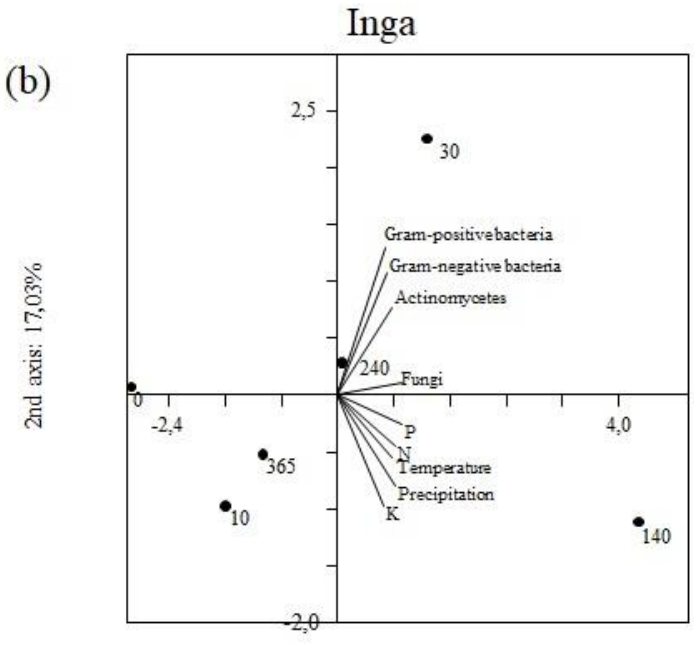

1st axis: : $71,95 \%$

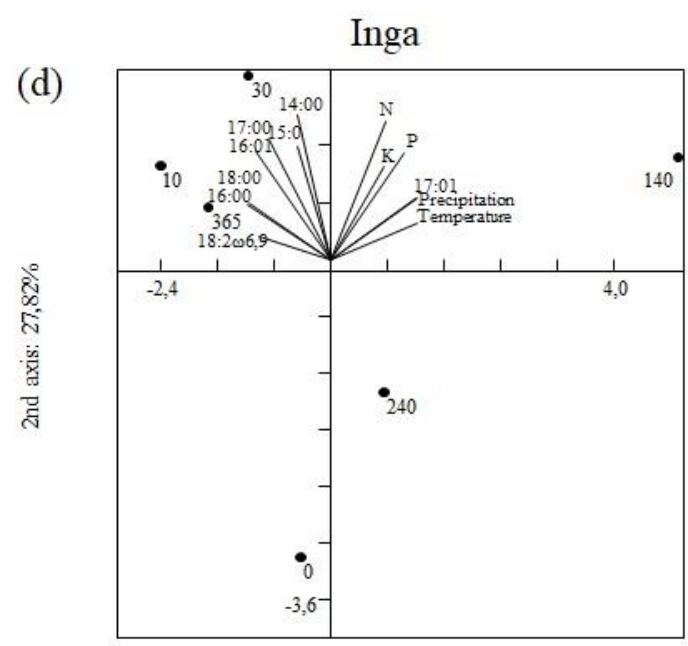

1st axis: $1: 53,76 \%$

Figure 1. Analysis of the principal components of the density of the microorganism groups, through plate culture $(\mathrm{a}, \mathrm{b})$, fatty acid profile $(\mathrm{c}, \mathrm{d})$, nutrient release rate $(\mathrm{N}=$ nitrogen, $\mathrm{P}=$ phosphorus, $\mathrm{K}=$ potassium), and precipitation and temperature over the 365 days of brazilwood and inga litter decomposition.

Figura 1. Análise dos componentes principais da densidade dos grupos de micro-organismos, através da identificação por meio do cultivo em placa $(\mathrm{a}, \mathrm{b})$ e por meio do perfil de ácidos graxos $(\mathrm{c}, \mathrm{d})$, da taxa de liberação de nutrientes $(\mathrm{N}=$ nitrogênio, $\mathrm{P}=$ fósforo, $\mathrm{K}=$ potássio), da precipitação e da temperatura ao decorrer de 365 dias de decomposição da serapilheira do pau-brasil e do ingá. 
For brazilwood, principal component analysis (PCA) for the evaluation of microorganisms using the plate culture method indicated the formation of two main axes that together explained $91.88 \%$ of the data variation (Figure 1a). The first axis explained $59.12 \%$ of the variation, and the variables that most contributed to its formation were fungi, actinomycetes, N, P, temperature, and precipitation (Figure 1a). The second axis explained $32.76 \%$ of the variation, and the variables gram-positive bacteria and gram-negative bacteria strongly contributed to its formation (Figure 1a). For the evaluation of microorganisms through the fatty acid profile, in this same tree species, the two main axes formed in the PCA together explained $76.8 \%$ of the data variation (Figure 1c). The first axis explained $52 \%$ of the variation, and the variables that most contributed to its formation were the biomarkers 17:1 (bacteria) and 18:2 66.9 (fungi), N, P, K, precipitation, and temperature (Figure 1c).

For inga, PCA also indicated the formation of two main axes, which together explained $88.98 \%$ of the data variation (Figure $1 \mathrm{~b}$ ). The first axis explained $71.95 \%$ of the variation, with a greater contribution from the variables fungi, actinomycetes, gram-positive bacteria, gram-negative bacteria, N, and K (Figure 1b). The second axis explained $17.03 \%$ of the variation, and the variables $\mathrm{N}$ and $\mathrm{P}$ contributed most to its formation (Figure 1a). Regarding the evaluation of microorganisms by fatty acid profile, for this same species, the two main axes together explained $81.58 \%$ of the data variation (Figure 1d). The first axis explained $53.76 \%$ of the variation, in which the

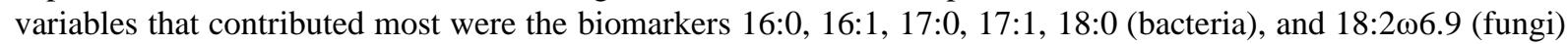
(Figure 1d). The second axis explained $27.82 \%$ of the data variation, and the variables that contributed most to its formation were N, P, and K (Figure 1d).

The Pearson correlation analysis (Table 4) showed correlations between nitrogen release rate and precipitation (brazilwood: $\mathrm{r}=0.99, \mathrm{p}=0$; inga: $\mathrm{r}=0.83, \mathrm{p}=0.04$ ) and between phosphorus release rate and precipitation (brazilwood: $\mathrm{r}=0.89, \mathrm{p}=0.01$; inga: $\mathrm{r}=0.91, \mathrm{p}=0.01$ ) for both species. Moreover, for brazilwood, it showed correlations between nitrogen release rate and temperature $(r=0.88, p=0.02)$ and between phosphorus release rate and temperature $(\mathrm{r}=0.91, \mathrm{p}=0.01)$. As for the plate culture method, brazilwood and inga behaved similarly with respect to the bacterial (both gram-negative and gram-positive) population peak after 30 days of collection, and the actinomycetes peak between 30 and 140 days. None of these groups of microorganisms correlated with nutrient release rates and abiotic factors. The tree species differed for the peak of fungal growth. For brazilwood, it occurred at 30 days; for inga, at 140 days. For the latter species, fungi correlated with phosphorus release rate $(r=0.93, p=0.006)$, temperature $(r=0.86, p=0.02)$, and precipitation $(r=0.88, p=0.02)$. Using the fatty acid profile method to identify microorganisms, fungi biomarkers did not correlate with phosphorus release rate. Both brazilwood and inga showed a higher concentration of the bacteria-biomarker fatty acid 17:1 at 140 days, which correlated with nitrogen release rate (brazilwood: $r=0.98, p=0.0003$; inga: $r=0.81, p=0.04$ ), phosphorus release rate (brazilwood: $\mathrm{r}=0.84, \mathrm{p}=0.03$; inga: $\mathrm{r}=0.88, \mathrm{p}=0.02$ ), temperature (brazilwood: $\mathrm{r}=$ $0.88, \mathrm{p}=0.02$; inga: $\mathrm{r}=0.90, \mathrm{p}=0.01$ ), and precipitation (brazilwood: $\mathrm{r}=0.99, \mathrm{p}=0.0001$; inga: $\mathrm{r}=0.96, \mathrm{p}=$ 0.003). The other fatty acids concentrated between 240 and 365 days, with no significant correlation between nutrient release rates and the abiotic factors studied.

Table 4. Pearson correlation of the studied variables.

Tabela 4. Correlação de Pearson das variáveis estudadas.

\begin{tabular}{cccccccccc}
\hline \multicolumn{10}{c}{ Colony-forming Unit } \\
\hline \multicolumn{10}{c}{ Brazilwood } \\
\hline Variable & Fungi & Actinomycetes & $\begin{array}{c}\text { Gram + } \\
\text { Bacteria }\end{array}$ & $\begin{array}{c}\text { Gram - } \\
\text { Bacteria }\end{array}$ & $\mathrm{N}$ & $\mathrm{P}$ & $\mathrm{K}$ & Temp. & Precip. \\
\hline Fungi & 0 & 0 & 0 & 0 & 0.37 & 0.34 & 0.77 & 0.35 & 0.37 \\
\hline Actinomycetes & 0.97 & 0 & 0.03 & 0.02 & 0.28 & 0.24 & 0.79 & 0.26 & 0.29 \\
\hline $\begin{array}{c}\text { Gram-positive } \\
\text { Bacteria }\end{array}$ & 0.93 & 0.85 & 0 & 0 & 0.81 & 0.74 & 0.90 & 0.75 & 0.82 \\
\hline $\begin{array}{c}\text { Gram-negative } \\
\text { Bacteria }\end{array}$ & 0.92 & 0.86 & 0.99 & 0 & 0.86 & 0.79 & 0.86 & 0.85 & 0.82 \\
\hline $\mathrm{N}$ & 0.42 & 0.52 & 0.12 & 0.09 & 0 & 0.01 & 0.06 & 0.02 & 0 \\
\hline P & 0.47 & 0.57 & 0.18 & 0.14 & 0.91 & 0 & 0.23 & 0.01 & 0.01 \\
\hline K & 0.16 & 0.14 & -0.07 & -0.09 & 0.79 & 0.57 & 0 & 0.33 & 0.08 \\
\hline Temp. & 0.47 & 0.55 & 0.16 & 0.09 & 0.88 & 0.91 & 0.48 & 0 & 0.01 \\
\hline Precip. & 0.44 & 0.52 & 0.12 & 0.07 & 0.99 & 0.89 & 0.76 & 0.92 & 0 \\
\hline Fungi & 0 & 0.05 & 0.09 & 0.06 & 0.06 & 0 & 0.19 & 0.02 & 0.02 \\
\hline
\end{tabular}

FLORESTA, Curitiba, PR, v. 50, n. 3, p. 1449 - 1456, jul/set 2020.

Baldez, F. et.al.

ISSN eletrônico 1982-4688

DOI: 10.5380/rf.v50 i3. 61279 


\begin{tabular}{|c|c|c|c|c|c|c|c|c|c|}
\hline Actinomycetes & 0.80 & 0 & 0.03 & 0.09 & 0.11 & 0.08 & 0.59 & 0.22 & 0.25 \\
\hline $\begin{array}{c}\text { Gram-positive } \\
\text { Bacteria }\end{array}$ & 0.74 & 0.84 & 0 & 0 & 0.32 & 0.18 & 0.67 & 0.46 & 0.49 \\
\hline $\begin{array}{c}\text { Gram-negative } \\
\text { Bacteria }\end{array}$ & 0.79 & 0.73 & 0.97 & 0 & 0.33 & 0.13 & 0.48 & 0.40 & 0.37 \\
\hline $\mathrm{N}$ & 0.78 & 0.71 & 0.49 & 0.49 & 0 & 0.02 & 0.10 & 0.08 & 0.04 \\
\hline $\mathrm{P}$ & 0.93 & 0.74 & 0.62 & 0.69 & 0.88 & 0 & 0.04 & 0.07 & 0.01 \\
\hline $\mathrm{K}$ & 0.62 & 0.28 & 0.22 & 0.36 & 0.73 & 0.82 & 0 & 0.28 & 0.05 \\
\hline Temp. & 0.86 & 0.59 & 0.38 & 0.42 & 0.76 & 0.78 & 0.53 & 0 & 0.01 \\
\hline Precip. & 0.88 & 0.56 & 0.35 & 0.44 & 0.83 & 0.91 & 0.80 & 0.92196 & 0.01 \\
\hline
\end{tabular}

Fatty Acid Profile

\begin{tabular}{|c|c|c|c|c|c|c|c|c|c|c|c|c|c|}
\hline \multicolumn{14}{|c|}{ Brazilwood } \\
\hline Variable & $14: 0$ & $15: 0$ & $16: 0$ & $16: 1$ & $17: 0$ & $17: 1$ & $18: 0$ & $18: 2 \omega 6.9$ & $\mathrm{~N}$ & $\mathrm{P}$ & K & Temp. & Precip. \\
\hline $14: 0$ & 0 & 0.86 & 0.15 & 0.35 & 0.02 & 0.85 & 0.11 & 0.41 & 0.78 & 0.74 & 0.89 & 0.95 & 0.89 \\
\hline $15: 0$ & -0.09 & 0 & 0.36 & 0.70 & 0.67 & 0.87 & 0.33 & 0.53 & 0.90 & 0.81 & 0.62 & 0.55 & 0.81 \\
\hline $16: 0$ & 0.65 & 0.46 & 0 & 0.72 & 0.25 & 0.18 & 0.00 & 0.04 & 0.19 & 0.22 & 0.75 & 0.19 & 0.19 \\
\hline $16: 1$ & 0.46 & -0.20 & 0.19 & 0 & 0.75 & 0.99 & 0.39 & 0.62 & 0.79 & 0.33 & 0.71 & 0.67 & 0.87 \\
\hline $17: 0$ & 0.86 & 0.22 & 0.56 & 0.17 & 0 & 0.65 & 0.18 & 0.56 & 0.67 & 0.68 & 0.40 & 0.57 & 0.61 \\
\hline $17: 1$ & -0.09 & -0.08 & -0.62 & 0.00 & 0.23 & 0 & 0.36 & 0.06 & 0.00 & 0.03 & 0.05 & 0.02 & 0.00 \\
\hline 18:0 & 0.72 & 0.48 & 0.95 & 0.43 & 0.62 & -0.45 & 0 & 0.17 & 0.31 & 0.22 & 0.98 & 0.26 & 0.33 \\
\hline $18: 2 \omega 6.9$ & 0.41 & 0.32 & 0.82 & -0.26 & 0.30 & -0.78 & 0.63 & 0 & 0.09 & 0.32 & 0.21 & 0.26 & 0.10 \\
\hline $\mathrm{N}$ & -0.15 & -0.06 & -0.62 & -0.13 & 0.22 & 0.98 & -0.49 & -0.73 & 0 & 0.01 & 0.06 & 0.02 & 0.00 \\
\hline $\mathrm{P}$ & -0.17 & -0.13 & -0.58 & -0.48 & 0.21 & 0.84 & -0.58 & -0.49 & 0.91 & 0 & 0.23 & 0.01 & 0.01 \\
\hline K & 0.07 & 0.25 & -0.17 & 0.19 & 0.42 & 0.80 & 0.01 & -0.59 & 0.79 & 0.57 & 0 & 0.33 & 0.08 \\
\hline Temp. & 0.03 & -0.31 & -0.61 & -0.22 & 0.29 & 0.88 & -0.54 & -0.54 & 0.88 & 0.91 & 0.48 & 0 & 0.00 \\
\hline Precip. & -0.07 & -0.12 & -0.61 & -0.08 & 0.26 & 0.99 & -0.48 & -0.73 & 0.99 & 0.89 & 0.76 & 0.92 & 0 \\
\hline \multicolumn{14}{|c|}{ Inga } \\
\hline $14: 0$ & 0 & 0.05 & 0.35 & 0.14 & 0.05 & 0.94 & 0.41 & 0.63 & 0.35 & 0.77 & 0.93 & 0.94 & 0.87 \\
\hline $15: 0$ & 0.80 & 0 & 0.70 & 0.22 & 0.02 & 0.70 & 0.65 & 0.87 & 0.74 & 0.80 & 0.79 & 0.63 & 0.64 \\
\hline 16:0 & 0.46 & 0.19 & 0 & 0.02 & 0.20 & 0.24 & 0.00 & 0.00 & 0.76 & 0.31 & 0.74 & 0.15 & 0.23 \\
\hline $16: 1$ & 0.67 & 0.59 & 0.87 & 0 & 0.01 & 0.35 & 0.13 & 0.13 & 0.97 & 0.68 & 0.98 & 0.18 & 0.34 \\
\hline $17: 0$ & -0.03 & -0.20 & -0.57 & -0.46 & -0.36 & 0 & 0.19 & 0.24 & 0.04 & 0.02 & 0.13 & 0.01 & 0.00 \\
\hline $17: 1$ & -0.03 & -0.20 & -0.56 & -0.46 & -0.36 & 0 & 0.19 & 0.24 & 0.04 & 0.02 & 0.13 & 0.01 & 0.00 \\
\hline 18:0 & 0.41 & 0.23 & 0.98 & 0.90 & 0.63 & -0.61 & 0 & 0.01 & 0.69 & 0.33 & 0.81 & 0.10 & 0.21 \\
\hline $18: 2 \omega 6.9$ & 0.25 & -0.08 & 0.93 & 0.68 & 0.31 & -0.56 & 0.91 & 0 & 0.70 & 0.26 & 0.82 & 0.24 & 0.31 \\
\hline $\mathrm{N}$ & 0.46 & 0.17 & -0.15 & 0.01 & 0.07 & 0.81 & -0.20 & -0.19 & 0 & 0.02 & 0.09 & 0.08 & 0.04 \\
\hline $\mathrm{P}$ & 0.15 & 0.13 & -0.49 & -0.21 & -0.07 & 0.88 & -0.48 & -0.53 & 0.87 & 0 & 0.04 & 0.06 & 0.01 \\
\hline $\mathrm{K}$ & -0.04 & -0.13 & -0.17 & -0.01 & -0.12 & 0.68 & -0.12 & -0.11 & 0.73 & 0.82 & 0 & 0.27 & 0.05 \\
\hline Temp. & -0.03 & -0.24 & -0.65 & -0.63 & -0.52 & 0.90 & -0.72 & -0.55 & 0.75 & 0.78 & 0.53 & 0 & 0.00 \\
\hline Precip. & -0.08 & -0.24 & -0.57 & $\begin{array}{l}-0.46 \\
\end{array}$ & -0.42 & 0.96 & -0.59 & $\begin{array}{l}-0.49 \\
\end{array}$ & 0.83 & 0.91 & 0.80 & 0.92 & 0 \\
\hline
\end{tabular}

FLORESTA, Curitiba, PR, v. 50, n. 3, p. 1449 - 1456, jul/set 2020. 


\section{DISCUSSION}

Microbiota degrades plant polymers physically and chemically through enzymatic actions, in which the higher the temperature and humidity, the higher the catalytic efficiency (MOREIRA; SIQUEIRA, 2002). This pattern may explain the correlation between nitrogen and phosphorus release rates and precipitation in the litter of both tree species studied, and between these release rates and temperature in brazilwood litter. The latter correlation corroborates the study of Narsian and Patel (2010), who report that the ideal temperature for phosphorus solubilization is around $28^{\circ} \mathrm{C}$.

The leaf structure of Inga is rich in lignin and polyphenols, which may affect leaf decomposition rate and, consequently, nutrient release rate (DUARTE et al., 2013). One of the main functions of fungi is to degrade lignin (AUER et al., 2014). This group of microorganisms is called oligotrophic, as they slowly and efficiently mineralize recalcitrant carbon sources (KORANDA et al. 2014). Moreover, they are responsible for phosphorus solubilization (SHARMA et al. 2013), producing enzymes called phosphatases (YAN, 2014). This relationship between fungi and phosphorus release rate may explain the correlations we found in inga, assuming that there is a need for more specialized groups of microorganisms to break these less soluble layers. As a result, favorable elements such as high pretipitation and ideal temperature, combined with the greater amount of fungi solubilizing phosphorus, led to the peak of the release rate of this nutrient at the same time as in brazilwood. Due to less recalcitrant structure of the latter species, we expected the nutrient release rate to be higher. This result corroborates the study by McGuire et al. (2012), who also observed a positive correlation between fungal richness and increased precipitation when analyzing a fungal microbial community in a tropical forest.

The significant correlation of the biomarker 17:1 showed the same pattern. This was the only fatty acid, among those evaluated, which correlated with nitrogen and phosphorus release rates in both tree species. This fact may have occurred because this fatty acid is a biomarker of gram-positive bacteria (NARENDRULA-KOTHA; NKONGOLO, 2017), and because these bacteria interfere with the mineralization of more complex substrates (WHITAKER et al., 2014), fitting into the group of oligotrophic microorganisms, as well as fungi (KORANDA et al., 2014). Therefore, the ideal conditions of precipitation and temperature acting together with these grampositive bacteria led to a higher rate of nitrogen and phosphorus releases, due to the breakdown of the most recalcitrant layer by this group of microorganisms. This biomarker (17:1) probably belongs to a specific group of gram-positive bacteria that the plate culture method was not able to detect due to selectivity.

\section{CONCLUSIONS}

Based on the results achieved, we conclude that:

- Regarding the degradation of brazilwood and inga litter, nutrient solubilization is more efficient under favorable precipitation and temperature conditions.

- Due to the recalcitrant leaf structure of inga, oligotrophic fungi are more present in these trees than in brazilwood trees.

- Comparing the two methods to identify microorganisms, the fatty acid profile method identified the presence of nutrient-solubilizing bacteria, and the culture method did not identify it. In contrast, the culture method identified fungi groups that the fatty acid profile method did not identify. Therefore, the methods can be considered complementary for this case study.

\section{REFERENCES}

AUER, C. G.; AMARO, T.; PIMENTEL, I. C.; ROCIO, P. Atividades degradativas de celulose e de fenóis por fungos isolados de acículas de Pinus taeda. Floresta, Curitiba, v. 44, n. 2, p. 179-184, 2014.

BOCOCK, K. L.; GILBERT, O. J. W. The disappearance of litter under different woodland conditions. Plant and Soil, Dordrecht, v. 9, n. 2, p. 179-185, 1957.

COURTY, P. E.; BUÉE, M.; DIEHIOU, A. G.; FREY-KLETT, P.; LE TACON, F.; RINEAU, F.; TURPAULT, S. U.; UROZ, S. GARBAYE, J. The role of ectomycorrhizal communities in forest ecosystem processes: new perspectives and emerging concepts. Soil Biology and Biochemistry, New York, v. 42, n. 5, p. 679-698, 2010.

DUARTE, E. M., CARDOSO, I. M., STIJNEN, T., MENDONÇA, M. A. F., COELHO, M. S., CANTARUTTI, R. B., MENDONÇA, E. S. Decomposition and nutrient release in leaves of Atlantic Rainforest tree species used in agroforestry systems. Agroforestry Systems, v.87, n.4, p.835-847, 2013.

EMBRAPA. Métodos de análises de solos. Rio de Janeiro: SNLCS, Embrapa. s.n.p., 1979.

FLORESTA, Curitiba, PR, v. 50, n. 3, p. 1449 - 1456, jul/set 2020.

Baldez, F. et.al.

ISSN eletrônico 1982-4688

DOI: $10.5380 /$ rf.v50 i3. 61279 
FOLCH, J.; LEES, M.; SLOANE, S. G. H. A simple method for the isolation and purification of total lipids from animal tissues. J biol Chem, Baltimore, v. 226, n. 1, p. 497-509, 1957.

JOSEPH, J. D.; ACKMAN, R. G. Capillary column gaschromatographic method for analysis of encapsulated fish oils and fish oil ethyl esters Collaborative study. Journal of AOAC International, Arlington, v. 75, n. 3, p. 488 506, 1992.

KORANDA, M.;KAISER, C.; FUCHSLUEGER, L.; KITZLER, B.; SESSITSCH, A.; ZECHMEISTERBOLTENSTERN, S.; RICHTER, A. Fungal and bacterial utilization of organic substrates depends on substrate complexity and $\mathrm{N}$ availability. FEMS microbiology ecology, Amsterdam, v. 87, n. 1, p. 142-152, 2014.

KORANDA, M.;KAISER, C.; FUCHSLUEGER, L.; KITZLER, B.; SESSITSCH, A.; ZECHMEISTERBOLTENSTERN, S.; RICHTER, A. Fungal and bacterial utilization of organic substrates depends on substrate complexity and $\mathrm{N}$ availability. FEMS microbiology ecology, Amsterdam, v. 87, n. 1, p. 142-152, 2014.

MALIK, A. A.; CHOWDHURY, S.; SCHLAGER, V.; OLIVER, A.; PUISSANT, J.; VAZQUEZ, P. G.; JEHMLICH, N.; BERGEN, M.; GRIFFITHS, R.; GLEIXNER, G. Soil fungal: bacterial ratios are linked to altered carbon cycling. Frontiers in microbiology, Lausanne, v. 7, p. 1247, 2016.

MCGUIRE, K. L.; FIERE, N.; BATEMAN, C.; TRESEDER, K. K.; TURNER, B.L. Fungal community composition in neotropical rain forests: the influence of tree diversity and precipitation. Microbial Ecology, Cambridge, v. 63, n. 4, p. 804-812, 2012.

MOREIRA, F. M. S.; SIQUEIRA, J. O. Transformações bioquímicas e ciclos dos elementos do solo. Microbiologia e bioquímica do solo. Editora UFLA, Lavras. 2002.

NARENDRULA-KOTHA, R.; NKONGOLO, K. K. Microbial response to soil liming of damaged ecosystems revealed by pyrosequencing and phospholipid fatty acid analyses. PloS one, San Francisco, v. 12, n. 1, p. e0168497, 2017.

NARSIAN, V.; SM, A. A. S.; PATEL, H. H. Rock phosphate dissolution by specific yeast. Indian journal of microbiology, New Delhi, v. 50, n. 1, p. 57-62, 2010.

PAN, Y.; BIRDSEY, R. A.; FANG, J.; HOUGHTON, R.; KAUPPI, P. E.; KURZ, W. A.; PHILLIPS, O. L.; SHVIDENKO, S. L. L.; LEWIS, S. L.; CANADELL, J. G.; CIAIS, P.; JACKSON, R. B.; PACALA, S.; MCGUIRE, A. D.; PIAO, S.; RAUTIAINEM, S. T.; SITCH, S.; HAYES, D. A large and persistent carbon sink in the world's forests. Science, New York, p. 1201609, 2011.

PINTO, H. C. A.; BARRETO, P. A. B.; DA GAMA-RODRIGUES, E. F.; DE OLIVEIRA, F. G. R. B.; DE PAULA, A.; RANULFO, A. A. Decomposição da serapilheira foliar de floresta nativa e plantios de Pterogyne nitens e Eucalyptus urophylla no sudoeste da Bahia. Ciência Florestal, v. 26, n. 4, p. 1141-1153, 2016.

SHARMA, S. B.; SAYYED, R. Z.; TRIVEDI, M. H.; GOBI, T. A. Phosphate solubilizing microbes: sustainable approach for managing phosphorus deficiency in agricultural soils. SpringerPlus, London, v. 2, n. 1, p. $587,2013$.

TEDESCO, M. J.; GIANELOO, C.; BISSANI, C. A.; BOHNEN, H.; VOLKWEISS, S. J. Análises de solo, plantas e outros materiais. Porto Alegre: UFRGS, p.174, 1995.

URIARTE, M.; TURNER, B. L.; THOMPSON, J.; ZIMMERMAN, J. K. Linking spatial patterns of leaf litterfall and soil nutrients in a tropical forest: a neighborhood approach. Ecological Applications, Washington, v. 25, n. 7, p. 2022-2034, 2015.

WHITAKER, J.; OSTLE, N.; MSNAMARA, N. P.; NOTTINGHAM, A. T.; STOTT, A. W.; BARGETT, R. D.; SALINAS, N.; CCAHUANA, A. J. Q.; MEIR, P. Microbial carbon mineralization in tropical lowland and montane forest soils of Peru. Frontiers in microbiology, Lausanne, v. 5, p. 720, 2014.

YAN, M.; YU, L.; ZHANG, L.; GUO, Y.; DAI, K.; CHEN, Y. Phosphatase activity and culture conditions of the yeast Candida mycoderma sp. and analysis of organic phosphorus hydrolysis ability. Journal of Environmental Science, Beijing, v. 26, n.11, p.2315-2321. 2014.

YOU, I.; WANG, J.; HUANG, X.; TANG, Z.; LIU, S.; SUN, O. J. Relating microbial community structure to functioning in forest soil organic carbon transformation and turnover. Ecology and evolution, v. 4, n. 5, p. 633647, 2014.

FLORESTA, Curitiba, PR, v. 50, n. 3, p. 1449 - 1456, jul/set 2020

Baldez, F. et.al.

ISSN eletrônico 1982-4688 